\section{New Gliding Record}

According to a Times correspondent, the world's long-distance record for motorless flights, set up on July 27 by Herr Wolfgang Hirth, who flew to Görlitz, in Silesia, about 212 miles, in six hours was beaten by Herr Heini Dittmar, of Darmstadt, on July 29. Leaving the Wasser Kuppe at 11.30 a.m., Dittmar reached Liban, in Czechoslovakia, about 235 miles distant, at 6.30 p.m. It was Herr Dittmar's first flight on a new type of glider called the Fafnir No. 2, newly built by the Research Institute for Motorless Flying at Darmstadt.

\section{Indian Research Expedition}

IT is announced that an expedition, of which Dr. Quaritch Wales is field director, will leave England for India in October next for the purpose of archæological exploration in Lower Burma and Siam. His Highness the Maharajah Gaekwar of Baroda has contributed $£ 500$ towards the expenses of the expedition, which will be known as the Gaekwar of Baroda Greater Indian Research Expedition. The work of organisation has been in the hands of a small committee of the Royal Asiatic Society, the India Society, and the School of Oriental Studies, under the chairmanship of Sir Francis Younghusband. The area which the expedition proposes to explore is one of the few districts of Further India and beyond which is still unexplored, and it may be anticipated that the expedition, under the leadership of Dr. Wales, who has already done valuable work in Siam, will yield material which will throw light on artistic and religious development in Further India and Siam and the cultural relations of these countries to the art, culture and religions of ancient India.

\section{Sixteen Element Oscillograph}

Is research into electrical engineering problems, the analysis of circuit performance and of the related physical phenomena frequently demands the simultaneous recording in correct time relationship of a large number of transient electrical quantities. The Research Department of the Metropolitan-Vickers Electrical Co. Ltd. has recently completed the design and construction of an electromagnetic oscillograph for recording no less than sixteen quantities simultaneously on a single film. Films up to 12 in. wide and $36 \mathrm{in}$. long may be used. The operation of the oscillograph is initiated automatically. The instrument requires the attention of one person only.

\section{Mendeléeff Periodic Law}

Refrerring to Prof. B. N. Menschutkin's letter in Nature of June 23, Dr. G. Rudorf, 46, Lanchester Road, Highgate, N.6, writes to point out that German translations of Mendeléeff's papers are readily avail. able in Ostwald's "Klassiker" (No. 68). A German translation of Mendeléeff's second long paper also forms part of supplement vol. 8 (1871) of Liebigs Annalen. Mendeléeff published a third table in 1880 (Ber. chem. Ges., vol. 13, p. 1796).

\section{Announcements}

Aт a special meeting of the Trustees of the Carnegie Trust for the Universities of Scotland held in London on July 27, Sir Arthur Rose was appointed chairman of the Trust in succession to the late Lord Sands.

The City of Leicester has published a guide to the works in its libraries dealing with science and its applications. The list is a classified catalogue of 65 pages, and contains a selection of the more modern books, and those considered by the compilers as likely to be of greatest help to serious readers.

Ar a meeting of the Royal College of Physicians of London on July 26 the following appointments were announced: Sir Henry Dale, as Harveian orator, 1935 (the forthcoming Harveian oration in October next will be delivered by Dr. James Collier); Dr. Daniel T. Davies as Bradshaw lecturer, 1935; Dr. J. S. Bolton as Lumleian lecturer, 1935; Dr. A. A. Moncrieff as Goulstonian lecturer, 1935; Dr. J. D. Rolleston as FitzPatrick lecturer, 1935; Dr. C. R. Harington as Oliver-Sharpey lecturer, 1935; Dr. C. G. Seligman as Lloyd Roberts lecturer, 1935 ; and Sir Bernard Spilsbury as Croonian lecturer, 1936. The Murchison scholarship was awarded to Stanley G. Browne, of King's College Hospital Medical School.

Applications are invited for the following appointments, on or before the dates mentioned :-A professor of physics in the Royal School of Engineering, Giza-The Vice-Principal, c/o The Director, Egyptian Education Office, 39, Victoria Street, London, S.W.I (Aug. 7). A civilian education officer in the Royal Air Force Educational Service-The Secretary (A.E.), Air Ministry, Adastral House, Kingsway, London, W.C.2 (Aug. 10). An inspector for the purposes of the Diseases of Animals Act, 1894-1927 in the Ministry of Agriculture and Fisheries-The Secretary, Ministry of Agriculture and Fisheries, 10, Whitehall Place, London, S.W.1 (Aug. 13). An assistant in the Electrical Engineering Department of the Coventry Technical College-The Director of Education, Council House, Coventry (Aug. 14). An adviser in agricultural zoology in the University College of South Wales and Monmouthshire, Cardiff-The Registrar (Sept. 1). A director of research of the Research and Standardization Committee of the Institution of Automobile Engineers-The Secretary, Watergate House, York Buildings, London, W.C.2 (Sept. 1). An engineer and ship surveyor-The Senior Staff Officer, Establishment Department (Mercantile Marine Branch), Board of Trade, Great George Street, London, S.W.I (Sept. 12). Readers in medicine, surgery, obstetrics and gynæcology, pathological chemistry and bacteriology at the British Post-Graduate Medical School-The Academic Registrar, University of London, S.W.7 (Sept. 17). A university professor of pathology and a professor of medicine at St. Bartholomew's Hospital Medical College-The Academic Registrar, University of London, S.W.7 (Sept. 18). A professor of anatomy in MeGill University, Montreal-The Secretary, Faculty of Medicine (Nov. 1). 